FEDERAL RESERVE BANK OF SAN FRANCISCO

WORKING PAPER SERIES

\title{
The Composition of Capital Inflows When Emerging Market Firms Face Financing Constraints
}

\author{
Katherine A. Smithy \\ U.S. Naval Academy \\ Diego Valderramaz \\ Federal Reserve Bank of San Francisco
}

May 2008

Working Paper 2007-13

http://www.frbsf.org/publications/economics/papers/2007/wp07-13bk.pdf

The views in this paper are solely the responsibility of the authors and should not be interpreted as reflecting the views of the Federal Reserve Bank of San Francisco or the Board of Governors of the Federal Reserve System. This paper was produced under the auspices of the Center for Pacific Basin Studies within the Economic Research Department of the Federal Reserve Bank of San Francisco 


\title{
The Composition of Capital Inflows When Emerging Market Firms Face Financing Constraints*
}

\author{
Katherine A. Smith ${ }^{\dagger}$ \\ U.S. Naval Academy
}

\author{
Diego Valderrama ${ }^{\ddagger}$ \\ Federal Reserve Bank of San Francisco
}

May 2008

\begin{abstract}
The composition of capital inflows to emerging market economies tends to follow a predictable dynamic pattern across the business cycle. In most emerging market economies, total inflows are pro-cyclical, with debt and portfolio equity flowing in first, followed later in the expansion by foreign direct investment (FDI). To understand the dynamic composition of these flows, we use a small open economy (SOE) framework to model the composition of capital inflows as the equilibrium outcome of emerging market firms' financing decisions. We show how costly external financing and FDI search costs generate a state contingent cost of financing such that the cheapest source of financing depends on the phase of the business cycle. In this manner, the financial frictions are able to explain the interaction between the types of flows and deliver a time-varying composition of flows, as well as other standard features of emerging market business cycles. If, as this work suggests, flows are an equilibrium outcome of firms' financing decisions, then volatility of capital inflows is not necessarily bad for an economy. Furthermore, using capital controls to shut down one type of flow and encourage another is certain to have both short- and long-run welfare implications.
\end{abstract}

JEL Codes: F32, F34, F41, G15

Key Words: Capital Inflow Composition, Financing Premium, Financial Frictions, Small Open Economy

\footnotetext{
${ }^{*}$ We thank the two anonymous referees and the editors, Gordon Hanson and Enrique Mendoza. Doireann Fitzgerald, Katheryn Russ, Vincenzo Quadrini, and Jonathan Heathcote provided helpful discussions. In addition, we are grateful to the participants at the IMF Conference on New Perspectives on Financial Globalization, USC Marshall School of Business FBE seminar, the Board of Governors seminars, the 2006 Stanford Institute for Theoretical Economics, Iowa State seminar, 2006 Spring Conference of the UC Santa Cruz Center for International Economics, the 2006 Spring Meetings of the System Committee on International Economic Analysis, the 2006 Latin American Meetings of the Econometric Society, and the 2006 Summer North American Meetings of the Econometric Society for many helpful comments. Gregory Snyders and Thien Nguyen provided excellent research assistance. The views expressed herein are those of the authors and do not necessarily reflect those of the Federal Reserve Bank of San Francisco, or the Federal Reserve System.

${ }^{\dagger}$ Corresponding author, Department of Economics, 589 McNair Road, Annapolis, MD 21402, USA. Email: ksmith@usna.edu.

${ }^{\dagger}$ Economic Research, 101 Market Street, MS 1130, San Francisco, CA 94105, USA. Telephone: +1 (415) 974-3225. Facsimile: +1 (415) 974-2168. Email: Diego.Valderrama@sf.frb.org.
} 


\section{Introduction}

The dynamic composition of gross private capital inflows to emerging market economies can be characterized by three stylized facts. First, total inflows are highly correlated with investment. Second, the individual components of the financial account behave differently depending on where the economy is in the business cycle. Third, correlations between the types of flows suggest there is some degree of substitutability between those flows.

Across many of the emerging market economies, total gross private inflows are positively correlated with investment. 1 As Table 1 reports, the correlation between investment and total inflows for emerging markets is on average 0.25. These correlations do vary by region with Eastern Europe showing the highest correlation of 0.338 , followed by Latin America at 0.254 and East Asia and the Pacific at 0.225 . Table 1 also reports this correlation on a country basis. While the individual country correlations show some heterogeneity in magnitude, qualitatively most countries share a significant positive relationship, with the exception of Indonesia and Chile. These positive correlations between capital inflows and investment suggest capital is flowing into the emerging market economies to finance investment needs rather than to smooth consumption directly.

While total gross inflows typically have a strong positive relationship with investment, the correlations between a particular type of flow and investment vary dramatically. Across regions, Table 1 shows that debt has a positive correlation with investment, foreign direct investment (FDI) has a negative correlation, and portfolio investment has essentially no correlation. This suggests that the type of capital flowing in depends on the stage of the business cycle. Specifically for Mexico, investment and debt have a positive correlation of 0.389 and investment and FDI have a negative correlation of -0.313 . To show that these correlations are not being driven exclusively by capital flow volatility during the 1994 economic crisis in Mexico, Figure 1 plots the ten-year rolling correlations from 1990 to 2006. While the crisis certainly seemed to have an impact on the flows, after 1994 the correlations remain fairly stable.

Data on the correlations between types of capital flows suggest that emerging market firms sub-

\footnotetext{
${ }^{1}$ In this paper, we focus on gross private inflows. All capital flow data is from the International Monetary Fund's International Financial Statistics (IFS). Foreign direct investment refers to line "Foreign direct investment in reporting economy, N.I.E." Portfolio investment refers to line "Portfolio investment, equity securities, liabilities." Debt refers to the sum of lines "Portfolio investment, debt securities, liabilities" and "Other investment, liabilities." Total inflows refers to the sum of the foreign direct investment, portfolio investment, and debt. The three series are generally shown as a fraction of gross domestic product.
} 
stitute one form of financing for another. Table 2 shows the correlation between flows for various countries. Across different countries and regions, the degree of substitutability (negative correlation) or complementarity (positive correlation) varies. In Mexico, FDI is negatively correlated with debt and portfolio equity inflows. Figure 2 shows how the correlations between inflows fluctuate over time in Mexico.

This paper explains these three stylized facts by modeling capital inflows as a source of financing for firms in a small open economy (SOE). Assuming financial frictions are nontrivial, a firm must decide not only how much to invest but how best to finance a particular project. Theoretically, going back to Modigliani and Miller (1958), if sources of financing are perfect substitutes, then a firm can simply focus on how much to invest and randomly choose financing without affecting the value of the firm. Since capital flows are a source of financing, in a world with no financial frictions a country's external capital structure would be indeterminate and there would be no visible pattern in the flows. Yet, the fact that a particular country does seem to favor one type of flow over another and that these flows tend to vary with the business cycle suggest that these forms of financing are not perfect substitutes and that the frictions force the inflow composition to vary over the business cycle.

The focus of our paper is on the dynamic composition of capital inflows. In contrast, most of the existing literature has focused on the long-run (i.e., static) determinants of the composition of capital inflows. The particular focus of the existing literature has been on explaining the revealed preference of FDI over other types of inflows. Razin et al. (1998) argue that while information asymmetries for foreigners inherently exist, these barriers can be overcome by investors actually producing in the emerging markets through FDI. Albuquerque (2003) argues that the lack of enforceability of claims in many emerging markets makes portfolio equity and debt less desirable than FDI for foreign investors. Hull and Tesar (2001) see the specialization benefits of FDI and the risk-sharing benefits of portfolio equity, suggesting the composition of flows can be complementary. While these factors may favor one type of flow, they are unlikely to be able to explain the dynamic composition of inflows and its relation to the business cycle. Moreover, these different theories focus in most part on the decision of the suppliers of funds (foreigners) to determine the resulting capital structure of the emerging market. Importantly, our model focuses on the demand considerations of the domestic firms given the constraints they face.

Since the early 1990s, there has been a surge in empirical work trying to establish whether changes 
in composition and volatility of capital flows are due to shifts in the supply of funds by foreign investors (push) or in the demand by domestic residents (pull). The policy concern is that, if capital is being pushed into emerging markets, it would be optimal for emerging market economies to design policies that encourage certain kinds of flows (e.g., long-term debt vs. short-term debt, FDI vs. portfolio flows) so that it would be more difficult for foreigners to reduce the supply dramatically if conditions changed in the emerging market. If financial frictions are nontrivial, however, government policies that target certain types of flows directly raise the cost of financing, leading to a reduction in welfare. The empirical findings suggest that indeed both "push" and "pull" factors are needed to understand the composition of flows. Faria and Mauro (2004) provide empirical evidence on the importance of institutions in determining the external capital structure of a country. Faria et al. (2007) study the determinants of the cross-sectional composition of inflows between 1996 and 2004 and they find that financial development increases the share of equity inflows. Wei (2000) studies the impact of corruption on the dynamic properties of capital flows to emerging economies.

In the model presented here, financial frictions are present and firms are forced to optimize over an array of financing choices. A firm chooses not only the type of financing instrument but the owner of that instrument by choosing to raise capital among domestic agents and foreigners. In our model, agents face two sources of financial frictions: issuance costs for international debt and equity, which are paid by domestic firms, and FDI search costs, which are paid by foreigners $2^{2}$ To motivate why issuance costs are nontrivial, we focus on the large body of literature showing that external finance is more costly to firms than using retained earnings. The theoretical underpinnings are typically attributed to the existence of transaction costs, moral hazard, or asymmetric information. Like Gomes et al. (2006) and Bond and Meghir (1994), we posit a cost function for raising capital externally instead of being concerned with the optimal contract. While the functional form of these costs may differ depending on the source of market imperfection, most models share two common features. Financing costs increase as more capital is raised and costs decrease as the size of the firm, measured by its capital stock, increases. To provide some motivation for these two properties of costly external finance, we appeal to the literature on transaction costs associated with public offerings. To launch an equity or debt offering, the domestic firms pay direct and indirect transaction costs based on the firm size

\footnotetext{
${ }^{2}$ The institutions within an emerging market have a large impact on the magnitude of the financial frictions. In terms of issuing costs, more stringent accounting standards make it easier for foreigners to value a firm. In terms of search costs, greater contract enforcement increases the probability of a match.
} 
and the size of the offering. The direct costs consist of administrative fees and underwriting costs. Data for the U.S. shows that while administrative fees are minimal, the underwriting discount can be substantial. According to Lee et al. (1996) direct costs are on average $7 \%$ of the proceeds of seasoned equity offerings, $11 \%$ for initial public offerings, and 2 to $3 \%$ for bond issuances. $3^{3}$

The second friction in our model is that multinational firms face search costs when purchasing a domestic firm. Due to different degrees of access to external financing, the value of a firm to a foreigner and to a domestic agent may differ. Therefore, multinationals have an incentive to purchase these financially constrained firms and provide them with less costly capital. We assume that finding a suitable company to buy takes effort and is therefore costly. Depending on the phase of the business cycle, the domestic firm may be more constrained, and thus the marginal benefit of buying that firm may be higher. As such, foreign firms are willing to exert more effort in trying to match $4^{4}$ This mechanism is very close in spirit to the one presented in Aguiar and Gopinath (2005). The main difference is that they argue that this channel of FDI financing occurs only during crises, while in our model, the need for FDI financing is present throughout the business cycle.

Financial frictions are able to explain the interaction between the types of flows and deliver a timevarying composition of flows within a framework that is consistent with other features of emerging market business cycles. 5 To test the ability of these financial frictions to explain observed patterns in capital flows, we calibrate our theoretical model to the Mexican economy and simulate the model. Because the model does not incorporate capital control policy, we choose Mexico for its history of relatively few restrictions on capital inflows. We find that for reasonable values of the costs we are able to match quite well Mexico's private capital inflow structure over time.

\footnotetext{
$\sqrt[3]{\text { Altinkilic and Hansen }} \sqrt{2000})$ argue that agency problems increase with the size of the issuance, generating increasing marginal costs.

${ }^{4}$ While we discuss FDI in terms of mergers and acquisitions, the same friction would apply to greenfield investments (setting up a subsidiary from scratch). If land were modeled explicitly as an input into production, the domestic landowner could be thought of as an agent who is severely constrained and who holds an option for future production. This suggests that both types of FDI should move together and can be explained by multinationals searching for potential buy-outs in terms of actual firms or options for future firms.

${ }^{5}$ The financing costs generate a counter-cyclical financing premium, raising the domestic interest rate above the world interest rate which is consistent with the theoretical findings of Eisfeldt and Rampini (2006).
} 


\section{An equilibrium model of capital flow determination}

The goal of this paper is to provide a theoretical model to help disentangle the co-movement between different types of capital flows across the business cycle. We start with a canonical model of firm financing decisions and we augment it to fit an international framework appropriate for emerging markets. The model can be summarized as an SOE model with financial frictions and two sets of agents: foreign and domestic. The domestic SOE consists of firms and households. The domestic firms are subject to non-diversifiable productivity shocks and make decisions to finance investment. The firms invest in profitable projects and have the power to trade bonds and equity with the rest of the world. Domestic firms face debt costs and the potential to be bought out by multinational firms. The households are risk averse and receive income from wages and from dividends paid by domestic firms. Domestic agents take the world interest rate as given. There are two kinds of foreign agents: the aforementioned multinational firms who search to purchase domestic firms and the global credit market of one-period bonds that determines the world real interest rate. Unlike the domestic firms that are limited by financial frictions, the multinational firms are unconstrained. However, they face search costs in finding a firm to purchase in the domestic economy.

\subsection{Domestic households}

A large number of identical, infinitely lived households inhabit the SOE. Households choose consumption and purchase shares in domestic companies to maximize the present value of lifetime utility $\mathcal{U}$ :

$$
\mathcal{U}=\sum_{t} \beta^{t} U\left(c_{t}\right)
$$

where $U$ is a concave, continuously differentiable, instantaneous utility function. Households receive utility from consumption of perishable goods, $c_{t}$. Labor supply, $l$, is inelastic. Households face the following period-t budget constraint:

$$
s_{t}\left(\operatorname{div}_{t}+\phi_{t} V_{t}^{\mathrm{NASH}}+\left(1-\phi_{t}\right) p_{t}\right)+b_{t}^{d}+w_{t} l=c_{t}+s_{t+1} p_{t}+\frac{1}{\left(1+r_{t}^{d}\right)} b_{t+1}^{d}
$$

The households receive income from labor, $w_{t} l$, and receipts on domestic discount bonds, $b_{t}^{d}$. In addition, households receive a payoff from owning shares in domestic firms. Given there are a large 
number of identical firms, we assume households purchase equity by buying a share in a mutual fund that is comprised of these firms. The payoff on equity consists of three components. First, households who hold shares $s_{t}$ are paid dividends $\operatorname{div}_{t}$. Second, while households cannot sell domestic shares abroad directly, each period multinationals buyout a portion of these domestic firms. $\phi_{t}$ represents the portion of domestic firms purchased by multinationals and therefore the portion of domestic households' assets that are transferred to the multinationals. If a buyout occurs, the domestic shareholders receive $V_{t}^{\mathrm{NASH}}$ per share. Third, households can sell shares $s_{t}$ with price $p_{t}$ to another domestic agent. Households make expenditures on consumption $c_{t}$, new shares $p_{t} s_{t+1}$, and discount bonds $b_{t+1}^{d}$ with

price $\frac{1}{\left(1+r_{t}^{d}\right)}$. The net domestic real interest rate is $r_{t}^{d}$. Given that labor is inelastically supplied, we normalize the labor supply to be equal to unity.

\section{Domestic households' optimality conditions}

The optimality conditions of the domestic households' problem in equation (2.1) are

$$
\begin{gathered}
\frac{1}{\left(1+r_{t}^{d}\right)}=E\left[\beta \frac{U_{c_{t+1}}}{U_{c_{t}}}\right] \\
p_{t}=E\left[\beta \frac{U_{c_{t+1}}}{U_{c_{t}}}\left(\operatorname{div}_{t+1}+\phi_{t+1} V_{t+1}^{\mathrm{NASH}}+\left(1-\phi_{t+1}\right) p_{t+1}\right)\right],
\end{gathered}
$$

where $U_{c_{t}}$ represents the marginal utility of period- $t$ consumption. The first condition is the standard Euler equation that determines the dynamics of domestic bond demand. The second condition equates the marginal cost of buying a share of equity and the marginal benefit that share provides.

Iterating equation (2.4) forward and imposing a non-bubble condition we can determine the price of an equity share as follows:

$$
p_{t}=E_{t}\left[\sum_{i=1}^{\infty} \beta^{i} \frac{U^{\prime}\left(c_{t+i}\right)}{U^{\prime}\left(c_{t}\right)}\left(1-\phi_{t+i-1}\right)\left(\operatorname{div}_{t+i}+\phi_{t+i} V_{t+i}^{\mathrm{NASH}}\right)\right]
$$

The price of a share is the discounted stream of dividends adjusted for the fact that a time varying portion of domestic assets may be purchased by a multinational. 


\subsection{Domestic firms}

The value of the domestic firm is derived from the discounted value of returns on labor and capital. In addition, the value reflects the chance that the firm may be sold abroad. Every period the firms in the SOE face a time-varying probability, $\Theta_{t}$, of being bought by a foreigner which is taken as given. The price of the sold firm, $V_{t}^{\mathrm{NASH}}$, is also taken as given and determined by the Nash bargain between the emerging market firm and the foreign firm, which we discuss later. Firms pay domestic households dividends and any proceeds from the sale of the firm to foreigners. Thus, the domestic value of the firm at any point in time, $V_{t}^{D}$, is given by

$$
V_{t}^{D}=\operatorname{div}_{t}+\Theta_{t} V_{t}^{\mathrm{NASH}}+\left(1-\Theta_{t}\right) E_{t}\left[M_{t+1} V_{t+1}^{D}\right]
$$

where $M_{t+1}$ is the stochastic discount factor and $\operatorname{div}_{t}$ are dividends paid to households.

There are a large number of identical firms in the SOE producing a single tradable good using a fixed labor input, $l$, and variable capital, $k_{t}$. Firms produce the single tradeable good using a constantreturns-to-scale (CRS) technology $y_{t}=\exp \left(\epsilon_{t}\right) f\left(k_{t}\right)$, where $\epsilon_{t}$ is a Markov productivity shock and $y_{t}$ is output. Given a sequence of discount factors, $M_{t+j}$, and purchase probabilities, $\Theta_{t}$, in a competitive equilibrium, domestic firms choose sequences of dividends, $\operatorname{div}_{t}$, desired capital stock, $k_{t+1}$, and foreign borrowing, $b_{t+1}$, to maximize the present value of dividends:

$$
V^{D}\left(k_{t}, b_{t} ; \epsilon_{t}, \zeta_{t}\right)=\max _{k_{t}+1, b_{t}+1} \operatorname{div}_{t}+\Theta_{t} V_{t}^{\mathrm{NASH}}+\left(1-\Theta_{t}\right) E\left[M_{t+1} V^{D}\left(k_{t+1}, b_{t+1} ; \epsilon_{t+1}, \zeta_{t+1}\right)\right]
$$

where

$$
\operatorname{div}_{t}=\exp \left(\epsilon_{t}\right) f\left(k_{t}\right)-w_{t}+(1-\delta) k_{t}-k_{t+1}-b_{t}\left(1+r_{t}^{*}\right)+b_{t+1}\left(1-\eta_{b}\left(\frac{b_{t+1}}{k_{t}}\right)\right)
$$

We assume that only domestic firms and not domestic households have access to foreign capital markets. Domestic firms issue debt abroad to finance domestic projects. International bonds pay an interest rate $r_{t}^{*}=r^{*} \exp \left(\zeta_{t}\right)$. The mean world interest rate is denoted by $r^{*}$, and $\zeta_{t}$ is a Markov world interest rate shock. The world interest rate is only contingent on the shock $\zeta_{t}$ and not on any domestic state variable. 
Domestic firms face frictions in financing domestic investment projects; therefore, the value of the firm is lower than if there were no constraints. Firms face adjustment costs when they want to access international capital markets to issue debt, $\eta_{b}\left(\frac{b_{t+1}}{k_{t}}\right)$. We assume that the bond issuance cost function is increasing and strictly positive for $b_{t+1}>0$. The motivation for the cost function is the notion that external financing is more costly than self financing. While the form of this function may differ depending on the source of market imperfection, Gomes et al. (2006) and Bond and Meghir (1994) find that most models exhibit increasing marginal costs after controlling for the existing firm size as proxied by capital stock ${ }^{6}$ The relevant proxy for firm size is today's capital stock rather than the future capital stock; therefore, $k_{t}$ is used in the financing cost function.

\section{Domestic firms' optimality conditions}

When firms want to invest, they can either use domestic financing (reduce dividends) or borrow from the world credit market $]^{7}$ The firms choose the optimal capital stock and source of financing to minimize costs and maximize returns. Both the marginal cost of financing and the type of funds used fluctuate over the business cycle.

The optimality conditions for the domestic firms' maximization problem in equation (2.7) are given by

$$
\begin{gathered}
1=\left(1-\Theta_{t}\right) E_{t}\left[M_{t+1}\left(\exp \left(\epsilon_{t+1}\right) \frac{\partial}{\partial k} f\left(k_{t+1}\right)+(1-\delta)+b_{t+2} \frac{\partial}{\partial k} \eta_{b}\left(\frac{b_{t+2}}{k_{t+1}}\right)\right)\right] \\
1-\eta_{b}\left(\frac{b_{t+1}}{k_{t}}\right)-b_{t+1} \frac{\partial}{\partial b} \eta_{b}\left(\frac{b_{t+1}}{k_{t}}\right)=\left(1-\Theta_{t}\right) E_{t}\left[M_{t+1}\left(1+r_{t}^{*}\right)\right] .
\end{gathered}
$$

The first condition, equation 2.9 , equates the cost of postponing dividend payments today with the marginal return to investing those dividends and producing more in the next period. The marginal return to investing in the firm is driven by the discounted return to capital tomorrow. This is given by the marginal product of capital in the next period net of depreciation and conditional on the firm remaining a domestic firm. One additional benefit reflected in the marginal return to investing is that next period's issuance cost falls which is captured in the $b_{t+2} \frac{\partial}{\partial k} \eta_{b}\left(\frac{b_{t+2}}{k_{t+1}}\right)$ term. The discount factor applied to the marginal return of investment is driven by the households' marginal rate of substitution,

\footnotetext{
${ }^{6}$ The current size of the firm is known at the time that the new debt is issued.

${ }^{7}$ The composition of domestic financing is indeterminant due to the fact that domestic equity and debt are perfect substitutes. The firm is indifferent between lowering dividends and issuing domestic bonds.
} 
$M_{t+1}$ and the search frictions $1-\Theta_{t}$. The search frictions alter the probability the domestic firm will be purchased, $\Theta_{t}$, and make investment more volatile. Firms have to make investment decisions, unsure whether or not they may be bought out. As the probability of being purchased increases, the marginal benefit of investing falls. The financial frictions also impact the discount rate indirectly through the marginal rate of substitution. Costly external financing lowers consumption via the resource constraint, raising the intertemporal price of consumption.

The second condition, equation $(2.10)$, equates the marginal benefit of borrowing, net of the cost of issuance, and the marginal cost of borrowing in terms of interest payments in the next period. These costs are discounted by the stochastic discount factor and are conditional on the firm not being sold to a foreigner through FDI. In this way, the search friction reduces the effective cost of borrowing for firms. Firms would like to borrow more if they are more likely to be purchased.

\section{Return to investment}

The financial frictions affect the returns to investing in the domestic economy in several ways. We can combine the domestic firms' optimality conditions for bonds in equation (2.10) and capital in equation 2.9 to obtain the following expression:

$$
E_{t}\left[\widetilde{\mathrm{MPK}_{t+1}}\right]=\frac{E_{t}\left[1+r_{t+1}^{*}\right]+\frac{\operatorname{COV}_{t}\left(M_{t+1}, 1+r_{t+1}^{*}\right)}{E_{t}\left[M_{t+1}\right]}}{1-\eta_{b}\left(\frac{b_{t+1}}{k_{t}}\right)-b_{t+1} \frac{\partial}{\partial b} \eta_{b}\left(\frac{b_{t+1}}{k_{t}}\right)}-\frac{\operatorname{COV}_{t}\left(M_{t+1}, \widetilde{\mathrm{MPK}_{t+1}}\right)}{E_{t}\left[M_{t+1}\right]},
$$

where the marginal product of capital, accounting for depreciation and decreased future bond issuance costs, is given by $\widetilde{\mathrm{MPK}_{t+1}}=\exp \left(\epsilon_{t+1}\right) \frac{\partial}{\partial k} f\left(k_{t+1}\right)+(1-\delta)+b_{t+2} \frac{\partial}{\partial k} \eta_{b}\left(\frac{b_{t+2}}{k_{t+1}}\right)$. Examining the first term in the returns for investment, costly debt finance directly raises the effective world interest rate, $\frac{E\left(1+r_{t+1}^{*}\right)}{1-\eta_{b}\left(\frac{b_{t+1}}{k_{t}}\right)-b_{t+1} \frac{\partial}{\partial b} \eta_{b}\left(\frac{b_{t+1}}{k_{t}}\right)}$. Risk induced by the foreign interest rate shocks $\operatorname{COV}_{t}\left(M_{t+1}, 1+r_{t+1}^{*}\right)$ also increases the effective borrowing rate. Both of these terms raise the expected marginal product of capital in the next period and depress desired investment. Costly finance, costly search, and the probability of being bought also affect the path of consumption through the resource constraint and through the impact on domestic interest rates. By rewriting equation (2.11), we can see how this 
first-order condition relates to the standard frictionless model;

$E_{t}\left[\widetilde{\mathrm{MPK}_{t+1}}\right]=E_{t}\left[1+r_{t+1}^{*}\right]-\operatorname{COV}_{t}\left(M_{t+1}, \widetilde{\mathrm{MPK}_{t+1}}\right)+\frac{\left[1+r_{t+1}^{*}\right]\left(\eta_{b}(\cdot)+b_{t+1} \frac{\partial}{\partial b} \eta_{b}(\cdot)\right)+\frac{\mathrm{COV}_{t}(M, r)}{E_{t}\left[M_{t+1}\right]}}{1-\eta_{b}(\cdot)-b_{t+1} \frac{\partial}{\partial b} \eta_{b}(\cdot)}$

Looking at 2.12 , we see the first two terms are standard determinants of the returns to investing. Due to the frictions, the third term shows that an increase in the magnitude of the financial friction will drive the investment return even further above the world interest rate. Because the returns to investing are driven by the domestic firms' financing decisions, investment and consumption are correlated and the Fisherian separation of savings and investment does not result. Thus, frictions increase the correlation between savings and investment, helping to explain the Feldstein and Horioka (1980) puzzle.

\section{The domestic interest rate}

Putting together the households' optimality condition for domestic bonds in equation (2.3) and the firms' optimality condition for international debt (2.10), we can express the domestic economies' return on bonds $r_{t}^{d}$ as a function of the world's return on bonds $r_{t}^{*}$ and the financial frictions:

$$
1+r_{t}^{d}=\frac{\left(1+r_{t}^{*}\right)\left(1-\Theta_{t}\right)}{1-\eta_{b}\left(\frac{b_{t+1}}{k_{t}}\right)-b_{t+1} \frac{\partial}{\partial b} \eta_{b}\left(\frac{b_{t+1}}{k_{t}}\right)-\operatorname{COV}_{t}\left(M_{t+1}, 1+r_{t+1}^{*}\right)\left(1-\Theta_{t}\right)}
$$

If there were zero cost of issuance, $\eta_{b}=0$, and no FDI, $\Theta_{t}=0$, equation (2.13) reduces to:

$$
1+r_{t}^{d}=E_{t}\left[1+r_{t}^{*}\right]+\left(1+r_{t}^{d}\right) \operatorname{COV}_{t}\left(M_{t+1}, 1+r_{t+1}^{*}\right)
$$

Any difference between the domestic interest rate and the world interest rate would be due to the covariance between the international interest rate and the stochastic discount factor. Given that in equilibrium the firms' stochastic discount factor equals the households' intertemporal marginal rate of substitution, deviations from interest rate parity would be generated by any additional risk to domestic consumption from world interest rate movements. This risk leads to domestic households engaging in precautionary savings. This interest rate wedge is a standard result of small open economy models. 
With financial frictions (positive cost of issuance and search), the relationship between the domestic interest rate and the world interest rate is determined by the direct impact of the frictions on equation (2.13) and by their indirect impact on the stochastic discount factor. The financial frictions generate a wedge between the interest rate determined on world credit markets and the domestic interest rate. There are two components of the wedge: one is driven by the probability the domestic firm will be bought out by a multinational and the other is driven by costly external financing. A higher probability of a firm being bought by a foreigner decreases the domestic interest rate relative to the world interest rate. The marginal cost of investing using debt falls because firms face a higher probability that they will not have to pay the debt back in the future.

This wedge varies with the business cycle. For example, if the domestic economy is in a recession and receives a positive productivity shock, domestic firms would like to invest. However, since their capital stock is relatively low at that point in the business cycle, the cost of borrowing abroad, $\frac{\partial \eta_{b}}{\partial b_{t+1}}$, is high and this drives the domestic interest rate up. Foreigners who do not face costs and constraints are more likely to want to invest. Therefore, multinationals are willing to exert more effort to increase their probability of matching, which raises $\Theta_{t}$. As the domestic firms invest and the economy expands, the financing premium falls and the domestic interest rate approaches the world interest rate.

\subsection{Foreign multinationals}

We assume that there is a search friction when foreign multinationals purchase domestic firms. We further assume that the foreign multinationals are unconstrained and have a zero outside opportunity. Finally, we assume that, once a domestic firm is found, the multinational and the domestic firm engage in bargaining to set the sale price of the domestic firm.

Let $V_{t}^{F}$ be the unconstrained value of domestic firms and $V_{t}$ be the constrained value of domestic firms. Given our assumption that multinationals are unconstrained (i.e., $\eta_{b}=0$ ), the unconstrained value of the firm is given by the following expression:

$$
V_{t}^{F}=E_{t}\left[\frac{1}{1+r_{t}^{*}}\left(\operatorname{div}\left(k^{f}\right)_{t+1}+V_{t+1}^{F}\right)\right]
$$

Implicit in this expression is the timing assumption that firms are taken over after dividends to domestic households are paid. We can iterate this expression of the value of the firm to obtain the 
usual result that the value of the firm to the foreigner is the discounted value of dividends. In the equation below, $k^{f}$ represents the optimal capital stock for the unconstrained multinational:

$$
V_{t}^{F}=E_{t}\left[\sum_{i=0}^{\infty} \prod_{j=0}^{i}\left(\frac{1}{1+r_{t+1+j}^{*}}\right) \operatorname{div}\left(k^{f}\right)_{t+1+i}\right] .
$$

The after-dividend value of the firm to the domestic agent, $V_{t}$, is given by iterating forward (2.7) and subtracting current dividends to obtain the following expression:

$$
V_{t}=E_{t}\left[\sum_{i=1}^{\infty} \beta^{i} \frac{U^{\prime}\left(c_{t+i}\right)}{U^{\prime}\left(c_{t}\right)}\left(1-\Theta_{t+i-1}\right)\left(\operatorname{div}\left(k^{d}\right)_{t+i}+\Theta_{t+i} V_{t+i}^{\mathrm{NASH}}\right)\right]
$$

The multinationals' valuations of the domestic firms and the domestic firms' own valuations differ for two reasons. First, the stochastic discount factors differ because the households in the emerging markets do not have access to foreign capital. Second, because the foreign multinationals are not constrained they make different choices concerning the optimal capital stock, so $k^{f} \neq k^{d}$, which is reflected in the dividend policy.

The surplus of a sale of a constrained firm, $\mathcal{S}$, is the difference between the constrained and unconstrained value of the firm:

$$
\mathcal{S}_{t}=\left[V_{t}^{F}-V_{t}\right] \geq 0
$$

The inequality comes from the fact that the domestic value of firm is the constrained value of the firm, while the value of the firm to foreigners is unconstrained.

The Nash-bargaining price, $V_{t}^{\mathrm{NASH}}$, divides the surplus from equation 2.17) between the domestic firm and the multinational based on the domestic firm's bargaining power, $\psi$;

$$
V_{t}^{\mathrm{NASH}}=\psi\left[V_{t}^{F}-V_{t}\right]+V_{t}
$$

The foreign multinational knows that it pays $V_{t}^{\mathrm{NASH}}$ if it finds a domestic firm.

We assume that the probability that a foreign multinational matches with a domestic firm is a function of search effort, $e_{t}$. Effort costs, $\chi\left(e_{t}\right)$, are expressed in terms of tradeable units and we assume that this cost is increasing in effort. Foreign firms choose search effort, $e$, to maximize the 
expected value of the surplus they receive minus their effort costs:

$$
\max _{e_{t}} \Theta\left(e_{t}\right)\left[V_{t}^{F}-V_{t}^{\mathrm{NASH}}\right]-\chi\left(e_{t}\right)
$$

where $\Theta\left(e_{t}\right)$ is the probability of a match, which depends on the effort spent on searching.

Working with the first-order conditions for the multinationals, we can see that the amount of FDI is driven by the difference between the domestic and multinational firm values:

$$
\frac{\partial}{\partial e} \Theta\left(e_{t}\right)\left(V_{t}^{F}-V_{t}^{\mathrm{NASH}}\right)=\frac{\partial}{\partial e} \chi\left(e_{t}\right)
$$

As the domestic value of the firm, $V_{t}$, increases, the valuation wedge, $\left(V_{t}^{F}-V_{t}^{\mathrm{NASH}}\right)$, falls forcing less FDI to occur and the share of domestic ownership to increase.

Other models have also attributed a valuation wedge as the impetus behind FDI flows. However, the reason for the valuation wedge can stem from a variety of factors. Chari et al. (2004) argue multinationals bring better institutions (e.g., better governance) and Alfaro and Charlton (2007) suggest multinationals offer knowledge transfers. Indeed, those "static" factors may be important in the long run in determining the degree of foreign ownership in an emerging market economy. In addition to these other alternative factors, we suggest here that access to financing plays a role in generating a wedge between the valuation of a firm to domestic residents and to foreign buyers. Unlike other theories, the benefit of this access to financing theory is that it can explain why changes in foreign ownership, FDI, tends to vary over the business cycle.

\section{Substitutability of inflows}

In the model, the key to why FDI flows and bond flows are negatively correlated is dependent on the volume and value of FDI flows moving separately. FDI is driven by two components, the change in foreign ownership (volume), $\Theta\left(e_{t}\right)$, and the value at which the domestic ownership rights are sold, $V_{t}^{\mathrm{NASH}}$. When desired capital next period is high, firms are willing to finance projects using costly external finance so debt increases, which in turn drives the domestic interest rate above the world interest rate. Because these financing costs are faced by domestic agents and not by the multinationals, the surplus that the multinationals can gain from a buyout increases. As the benefit to matching 
rises, multinationals increase their effort to search, increasing the probability a firm is purchased, $\Theta\left(e_{t}\right)$. However $V_{t}^{\mathrm{NASH}}$ at this time is relatively low, since the capital stock is low in the domestic economy, pushing down the option value for the domestic agents. As the domestic economy expands, the capital stock increases, driving up the option value and increasing $V_{t}^{\mathrm{NASH}}$, and thus FDI. At the very beginning of an economic expansion, more domestic firms are purchased by foreigners but at a relative discount, causing FDI flows to be small. It is only later in the cycle as foreigners are forced to pay a higher price to purchase an emerging market firm that FDI flows increase.

\section{Incorporating portfolio equity}

For many of the emerging market economies in recent years, portfolio equity has also been a source of capital. The role of portfolio equity in the composition of capital flows can easily be added to the existing framework with the addition of two assumptions. The first assumption is that dividends face a lower bound. Both reducing dividends and issuing secondary shares are essentially the same use of equity. Therefore, if portfolio equity issuance is costly, like debt, then the firm would always choose to reduce dividends rather than pay the external financing costs. In order to make the portfolio equity cost relevant, dividends must be limited. Second, we assume that equity issuance must be non-negative, so that the dividend constraint may bind.

The value of the domestic firm is derived from the discounted value of returns on labor and capital. To account for secondary offerings, we must adjust the value of the firm to reflect both the possibility that new shares, $\sec _{t}$, may be issued and that there is some chance the firm will be purchased by a foreigner. To incorporate the impact of new issuance on firm value, we follow Fazzari et al. (1988) and adjust dividends, $\operatorname{div}_{t}$, by the dilution that arises from the secondary equity issuance, $\sec _{t}$ :

$$
\widetilde{\operatorname{div}_{t}} \equiv \operatorname{div}_{t}-\sec _{t}
$$

where $\widetilde{\operatorname{div}_{t}}$ is the measure of adjusted dividends.

The total value of the firm, $V_{t}^{D}$, is the present value of dividends adjusted for the present value of new shares that would have to be bought by current equity holders to maintain a proportional

claim on the firm. We assume that the domestic firms pay an equity issuance cost $\eta_{\text {sec }}\left(\frac{\sec _{t}}{k_{t}}\right)$ similar to the bond issuance cost that also reduces dividends paid to households. With secondary offerings 
as an additional financing option, the maximization problem for the firm in equation (2.7) is altered somewhat as indicated below;

$$
V^{D}\left(k_{t}, b_{t} ; \epsilon_{t}, \zeta_{t}\right)=\max _{k_{t}, b_{t}, \mathrm{sec}_{t}} \widetilde{\operatorname{div}_{t}}+\Theta_{t} V_{t}^{\mathrm{NASH}}+\left(1-\Theta_{t}\right) E\left[M_{t+1} V^{D}\left(k_{t+1}, b_{t+1} ; \epsilon_{t+1}, \zeta_{t+1}\right)\right],
$$

subject to the two additional constraints:

$$
\begin{aligned}
& \operatorname{div}_{t} \geq 0 \\
& \sec _{t} \geq 0 .
\end{aligned}
$$

If a firm chooses to issue new shares, all the existing owners choose to buy the shares to maintain their existing ownership portion of the firm. This holds true for both the domestic and foreign owners. When the multinationals buy up these publicly traded shares, capital flows into the domestic economy in the form of portfolio equity.

\subsection{Market clearing conditions}

For the domestic economy, it must be the case that domestic bonds are in net zero supply across all individuals $i$ : $\sum_{i} b_{t}^{d}=\sum_{i} b_{t+1}^{d}=0, \quad \forall i$. We normalize the sum of domestic shares in domestic firms, $\sum_{i} s_{t}^{i}=1$. Given the large number of identical domestic firms, following Pissarides (1985) the probability a firm is taken over is equal to the portion of domestic firms taken over ${ }^{8}$ Therefore, $\Theta_{t}$, the probability of a firm buyout is equal to $\phi_{t}$, the portion of domestic assets taken over by multinationals. Given $\Theta_{t}=\phi_{t}$ the law of motion for the stock of FDI, $\left(1-\gamma_{t}\right)$, follows below:

$$
\gamma_{t+1}=\gamma_{t}\left(1-\phi_{t}\right)+\left(1-\gamma_{t}\right) \kappa
$$

where $\kappa$ is an exogenous separation rate. Domestic ownership for the entire economy falls as the portion of domestic firms that match increases. Gross FDI inflows may be zero or even negative due to the exogenous separation. When a merger falls apart, and the multinational separates from the domestic firm, the foreign ownership is assumed back into the domestic capital stock. Considering that

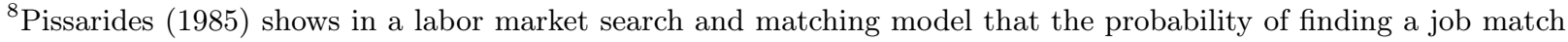
determines the economy wide employment rate.
} 
some firms are owned by domestic agents and some by foreigners, the sum of all dividends paid out to domestic agents must be equal to $\gamma_{t} d i v_{t}$. Likewise the payout to the households by the multinationals is $\gamma_{t} V_{t}^{\mathrm{NASH}} \phi_{t}$.

Using these market clearing conditions and the household budget constraint, equation (2.2), we can define the resource constraint for the economy:

$$
c_{t}=\left(\gamma_{t} \operatorname{div}_{t}+\gamma_{t} \phi_{t} V_{t}^{\mathrm{NASH}}-V_{t}\left(1-\gamma_{t}\right) \kappa\right)+w_{t} .
$$

Thus, aggregate consumption equals the sum of the share of dividends paid to domestic residents, net proceeds from buyouts by foreigners, and wage income.

We define gross investment as $i_{t} \equiv k_{t+1}-k_{t}(1-\delta)$. Substituting into the aggregate household budget constraint in equation (2.25) the definition of investment and dividends in equation (2.8) and ignoring issuance costs, we derive the following expression:

$$
0=\underbrace{\underbrace{y_{t}-c_{t}-i_{t}}_{\text {net exports }}+\underbrace{-\left(1-\gamma_{t}\right) \operatorname{div}_{t}-r_{t}^{*} b_{t}}_{\text {net factor payments }}}_{\text {current account }}+\underbrace{\overbrace{b_{t+1}-b_{t}}^{\text {bonds }}+\overbrace{\left(\gamma_{t} \phi_{t} V_{t}^{\mathrm{NASH}}\right)-V_{t}\left(1-\gamma_{t}\right) \kappa}^{\text {FDI }}+\overbrace{\left(1-\gamma_{t}\right) \sec _{t}}^{\text {portfolio flows }}}_{\text {financial account }} .
$$

This equation is simply the balance of payments for the model economy, which allows us to match the model to the data.

In the decentralized equilibrium, since the households own the firms, the discount rate of the firm reflects the households' marginal rate of substitution:

$$
M_{t+i} \equiv \frac{1}{1+r_{t+i}^{d}}=\beta^{i} \frac{U^{\prime}\left(c_{t+i}\right)}{U^{\prime}\left(c_{t}\right)} .
$$

\subsection{Stochastic processes and competitive equilibrium}

To complete the model, we specify the stochastic process for the productivity shocks, $e_{t}$, and the world interest rate shocks, $z_{t}$. We assume that both of these shocks follow a first-order autoregressive process and they are possibly correlated. We discretize the process for the two shocks using a simple persistence rule.

Given a stochastic process of productivity shocks, interest rate shocks, and initial conditions, a 
competitive equilibrium is defined by stochastic sequences of allocations $\left[c_{t}, l, b_{t+1}, k_{t+1}, e_{t}\right]$, prices $\left[w_{t}, r_{t}^{d}\right]$, and value functions, $\left[V_{t}^{\mathrm{NASH}}, V_{t}^{D}, V_{t}^{F}\right]$, such that: (a) domestic firms maximize dividends subject to the constant returns-to-scale technology, taking factor and goods prices as given, (b) households maximize utility subject to the budget constraint taking as given factor prices, goods prices, and asset prices, (c) foreign multinationals maximize their surplus, and (d) the market-clearing conditions for equity, labor, and goods markets hold.

\section{Recursive equilibrium and numerical solution technique}

The model's competitive equilibrium is solved by reformulating it in recursive form and applying a numerical solution method in a similar manner to Mendoza and Smith (2006). The challenge of the numerical solution is to keep track of optimizations for all four agents: domestic households, domestic firms, foreign investors (debt and equity holders), and foreign multinational firms.

To facilitate computation of the equilibrium, we represent the domestic economy's problem (household and domestic firm) as a domestic social planner's problem. The domestic social planner makes investment, international borrowing, and secondary offering allocations. The advantage to solving the problem in this manner is that one can use the concavity of the utility function to get a unique solution on a coarser grid, which is more efficient given the multiple endogenous state variables.

In a similar manner to Mendoza and Oviedo (2006) and Kehoe (1987), the equilibrium between the domestic social planner and the multinationals is solved as a Nash Equilibrium of a two player dynamic game under uncertainty where both players move simultaneously. To solve for the equilibrium, the domestic social planner and the multinationals formulate there optimal plans taken as given a conjecture of the optimal plans' of the other agent. Given the multinational's conjectured

effort level in searching for a domestic firm to buy, the domestic social planner infers a probability of a match and the selling price of the firm, which are used to determine the optimal investment, international borrowing, and secondary offering allocations. Likewise, given a conjecture of the domestic social planners capital and debt decisions, the multinational infers the buyout price and solves for the optimal effort level in procuring a match.

The domestic social planner faces the following state variables: capital, $k$, and international borrowing, $b$, as the endogenous state variables and $\epsilon$ and $\zeta$ as the exogenous states. The domestic social 
planner takes as given $\widetilde{V^{\mathrm{NASH}}}$ and $\widetilde{\phi}$, which are the price that the agents receive if part of the capital stock is sold to multinationals and the portion of domestic assets sold, respectively. The optimal allocation for the domestic social planner is characterized by the value function, $\mathbb{V}^{S}$, that solves the following recursive problem 9

$$
\mathbb{V}^{S}(k, b ; \epsilon, \zeta)=\max _{k^{\prime}, b^{\prime}} \frac{c^{1-\sigma}-1}{1-\sigma}+E \beta \mathbb{V}^{S}\left(k^{\prime}, b^{\prime} ; \epsilon^{\prime}, \zeta^{\prime}\right)
$$

subject to

$$
\begin{aligned}
c \leq & {\left[\exp (\epsilon) f(k)-w+(1-\delta) k-k^{\prime}-b\left(1+r^{*} \exp (\zeta)\right)+b^{\prime}\left(1-\eta_{b}\left(\frac{b^{\prime}}{k}\right)\right)\right] } \\
& +w+\gamma \widetilde{\phi}(k, b ; \epsilon, \zeta) \widehat{V^{\mathrm{NASH}}}(k, b ; \epsilon, \zeta) \\
& \gamma^{\prime}=\gamma(1-\widetilde{\phi}(k, b ; \epsilon, \zeta))+(1-\gamma) \kappa
\end{aligned}
$$

The solutions of this problem are represented by the optimal decision rules for capital $\hat{k}^{\prime}(k, b, \epsilon, \zeta)$ and bonds $\hat{b}^{\prime}(k, b, \epsilon, \zeta)$. Using the decision rules, the value of the firm to domestic agents is determined by equation 2.16), giving us $\hat{V}(k, b, \epsilon, \zeta)$.

The multinationals use their conjecture of $\widetilde{V}(k, b ; \epsilon, \zeta)$ to determine $\widehat{V^{\mathrm{NASH}}}$ and then choose their effort level in matching, $\hat{e}(k, b ; \epsilon, \zeta)$, to satisfy 2.20 . Knowing how much effort the multinational is willing to exert directly determines the probability of a match $\hat{\Theta}(k, b ; \epsilon, \zeta)$.

This equilibrium, if it exists, is a competitive equilibrium for the small open economy. From the Bellman equation (3.1) for the domestic firm, we can see the first order conditions that result from the standard Benveniste-Sheinkman equation equal the Euler equations associated with the domestic firms' first order conditions with respect to capital and debt in equations $(2.9)$ and $(2.10) .10$ On the multinationals side we use the first order conditions to determine the decision rule for search effort, $e_{t}$, guaranteeing the competitive equilibrium outcome.

The general outline of the solution algorithm is to solve the social planner's problem, given the conjecture of the portion of the domestic assets sold to the foreigners, $\widetilde{\phi}(k, b, \epsilon, \zeta)$ and the price at

\footnotetext{
${ }^{9}$ Notice that here we are showing the problem assuming the firms can also issue secondary shares.

${ }^{10}$ The first order conditions to the social planner's problem differ slightly from the competitive equilibrium in that the social planner takes into account the exogenous separation rate. As long as the separation rate and FDI stocks are small the difference is trivial.
} 
which the domestic firms are sold, $\widetilde{V^{\mathrm{NASH}}}(k, b, \epsilon, \zeta)$, using standard dynamic programming techniques. Given the optimal allocations of consumption, investment, and financing, the value of the financially constrained firm is determined. This is then used to determine $\widehat{V^{\mathrm{NASH}}} \cdot \widehat{V^{\mathrm{NASH}}}$ is plugged into the foreign multinationals' first-order conditions to determine the multinationals' effort levels, $e_{t}$, which in turn determines $\widehat{\Theta}(k, b, \epsilon, \zeta)$. In equilibrium $\hat{\Theta}=\hat{\phi}$, so $\hat{\Theta}(k, b, \epsilon, \zeta)$ and $\widehat{V^{\mathrm{NASH}}}$ become the new conjectures for the domestic social planner. The process continues until $\widehat{V^{\mathrm{NASH}}}(k, b, \epsilon, \zeta)=\widehat{V^{\mathrm{NASH}}}(k, b, \epsilon, \zeta)$ and $\hat{\Theta}(k, b, \epsilon, \zeta)=\widetilde{\phi}(k, b, \epsilon, \zeta)$.

The domestic social planner's problem, as given by the recursive equation (3.1), is solved by value function iteration. The value function is iterated, alternating between a full optimization and a recursion of the decision rules, until the value function does not change over successive iterations. The state space for capital stock includes $N K$ discrete nodes and the state space of bond positions includes $N B$ discrete nodes. The state space of endogenous states is thus given by $90 \times 40$ elements.

\subsection{Functional forms and baseline calibration}

To evaluate the model numerically, we make assumptions regarding the functional forms of the production function, the instantaneous utility function, the financial frictions, and the search intensity process. For the production function, we use the usual constant-returns-to-scale Cobb-Douglas form:

$$
f(k, l)=l^{\alpha} k^{1-\alpha}=k^{1-\alpha}
$$

where labor share of income is given by $\alpha$.

We assume that the instantaneous utility function is of the constant relative risk aversion (CRRA) form:

$$
U(C)=\frac{c^{1-\sigma}-1}{1-\sigma}
$$

The CRRA parameter is equal to $\sigma$.

The functional forms for the adjustment costs of bonds and secondary offerings are quadratic:

$$
\begin{aligned}
\eta_{b} & =\frac{\eta_{b}}{2}\left(\frac{b^{\prime}-b}{k}\right)^{2} \quad \text { and } \\
\eta_{\text {sec }} & =\frac{\eta_{\text {sec }}}{2}\left(\frac{\mathrm{sec}}{k}\right)^{2} .
\end{aligned}
$$


Finally, we assume that the probability of a match for the foreign firms is given as a logistic function of effort, $e$ :

$$
\Theta(e)=\frac{\pi e}{1+\pi e},
$$

where $\pi$ determines the elasticity of the match probability with respect to effort. A low level of $\pi$ means that the probability of a match is not very sensitive to search effort. In our model for a given cost of effort, if the elasticity $\pi$ is low, then domestic firms' value has to fall far below the unconstrained value of the firm to induce much search effort and a large number of FDI transactions. If, alternatively, the elasticity is high, then a small deviation of the firms' domestic value from the unconstrained value induce more search effort and more FDI transactions.

In terms of the calibration, we follow standard practice in the real business cycle (RBC) literature and set our model's parameters to match standard features of Mexican data and international data. We first determine the values for technology and preference parameters $(\alpha, \sigma, \beta)$. We find that Mexican data from the Mexican Statistical Institute (INEGI) suggests an average labor income share for the period 1988-96 of 0.341. Compared to evidence from other countries, this share seems quite low 11 Hence, we adopt instead a labor share $\alpha$ equal to 0.65 , which is in line with international evidence. In terms of preference parameters, we choose the coefficient of relative risk aversion $\sigma$ equal to 2.0, roughly in line with other international RBC studies. The gross annual real interest rate is set to $6 \%$. We set the rate of time preference, $\beta$ equal to 0.984 , which is the inverse of the real interest rate 12 The calibration yields a deterministic stationary state that replicates Mexico's 1970-95 average GDP shares of private consumption and investment at current prices. Using data from the World Bank's Development Indicators, the consumption share is equal to 0.684 and the investment share is equal to 0.217 . Our model yields a steady state consumption share equal to 0.687 and an investment share equal to 0.307 .

We now discuss the calibration of the financial frictions parameters $\left(\eta_{b}, \eta_{\sec }, \gamma, \pi, \psi, \kappa\right)$. We set the debt issuance cost parameter $\eta_{b}$ equal to 0.075 so that, in steady state, debt is roughly $13 \%$ of GDP, which is consistent with the Mexican data if only private flows are examined. To set the equity issuance cost parameter, we appeal to the empirical evidence on transaction costs for public offerings. To launch an equity or debt offering, domestic firms pay direct and indirect transaction costs based

\footnotetext{
${ }^{11}$ See Mendoza (2006) for more discussion on the controversy surrounding measures of labor income shares for Mexico.

${ }^{12}$ The functional form assumed for the debt issuance costs pins down the steady state debt level.
} 
on the firm size and the size of the offering. For the costs of equity issuance, the direct costs consist of administrative fees and underwriting costs. Data for the U.S. show that while administrative fees are minimal, the underwriting discount can be substantial. According to Lee et al. (1996) direct costs are $7 \%$ on average of the proceeds of seasoned equity offerings, $11 \%$ for IPOs, and $2-3 \%$ for bonds issuances. International offerings tend to be significantly higher. Issuing American Depository Receipts on the New York Stock Exchange, for instance, requires costly conversion to U.S. accounting standards and many additional fees. We set the secondary issuance cost parameter $\eta_{\text {sec }}$ equal to 0.04 . In steady state, the domestic share of the capital stock $\gamma$ is 0.92 , which is consistent with the findings of Mendoza and Smith (2006). In terms of the search parameters, the bargaining power of the domestic household is $\psi=0.1$, the elasticity of the matching probability is $\pi=0.5$, and the rate of separation $\kappa$ is set to 0.0788 .

Given the Markov process of productivity shocks, the standard deviation and first-order autocorrelation of GDP match the standard deviation and first-order autocorrelation of the HP-filtered quarterly cyclical component of Mexico's GDP reported in Mendoza (2006). In terms of the simple persistence rule, this requires $\epsilon_{H}=0.0178$ and the autocorrelation of the shock equal to 0.683 .

\section{Quantitative results}

Given the calibrated parameters, we follow the numerical solution technique outlined in Section 3 to derive the decision rules for the state variables. The decision rules are then used to calculate simulated business cycle statistics. The goal of the quantitative results is twofold. First, we compare the business cycle statistics of the model with frictions to the nearly frictionless case to assess the quantitative impacts of the frictions. Second, we compare the business cycle statistics of the simulated data to the actual data to determine if the model can capture capital flow dynamics in Mexico.

\subsection{Business cycle dynamics}

The key to our model's ability to capture the dynamics of capital inflows is that financial frictions determine how a firm finances its investment. Since the limiting distribution of our endogenous state variables determine the moments for all the macro aggregates, we first examine the impact of the financial frictions on the limiting distribution of both bonds and capital. Figure 3 compares the 
distribution of capital in a nearly frictionless economy to one in which the financial frictions are present. The frictions tend to lower investment, shifting the distribution of capital to the left and resulting in a slightly lower mean capital stock. While the frictions have a relatively small impact on capital, the distribution of bonds differs dramatically under financial frictions, as evident in Figure 4. Small changes in costs have a large impact on the distribution of debt, as firms choose other means of financing.

To show the impact of the financial frictions on the business cycle statistics, Table 4 compares simulated macro aggregates from the model with frictions to both the nearly frictionless model and the actual data. Examining the standard deviations (both absolute and relative to GDP) of consumption, both models tend to underestimate consumption volatility. Consistent with the theory, frictions make consumption smoothing more costly; the standard deviation of consumption relative to GDP increases from 0.44 in the frictionless case to 0.51 in the benchmark calibration. The relative standard deviation of consumption under the benchmark calibration still falls short of the 1.60 found in the Mexican data. The investment volatility falls dramatically as a result of the frictions. With frictions, the relative standard deviation of investment, 4.38 , is close to the 3.71 observed in the data. In the model, even without explicit capital adjustment costs, the financial frictions cut investment volatility in half relative to the nearly frictionless case. Along with investment, the current account volatility also falls sharply, but remains almost twice as volatile relative to GDP as in the data.

We turn to the correlations between the macro aggregates in the last two columns of Table 4 . Consistent with the notion of Fisherian separation, in the frictionless model consumption and investment dynamics are nearly uncorrelated (correlation of 0.02). Due to reduced risk sharing associated with increased financial frictions, the correlation between investment increases to 0.23 in the benchmark parameterization. The correlation is still below 0.55 found in the data. Due to the lack of impediments to capital mobility, in the frictionless model there is almost a perfect negative correlation between the current account and investment. With frictions, consumption and investment begin to move together and lessen capital flows in response to productivity shocks, lowering the correlation between the current account and investment.

Table 5 shows the dynamic composition of flows over the business cycle as determined by costly external financing and search costs. Since the composition of capital flows is indeterminate in the frictionless case, we only compare the benchmark model moments to the Mexican data. The first two 
columns of Table 5 report the correlation of the different types of inflows with GDP and investment. In qualitative terms, the model matches well the correlation between the different types of flows with investment and with GDP. Quantitatively, the model does a much better job at tracking the correlations with investment than with GDP. Consistent with the first stylized fact, in the model the correlation between investment and total inflows, measured as a percent of GDP, is positive. The model overstates the relationship somewhat. This positive correlation is consistent with the theory that capital inflows are used to finance investment. Consistent with the second stylized fact, the correlation of each type of flow with investment varies dramatically, mirroring the data. While portfolio equity and debt inflows, each measured as a percent of GDP, both have a positive correlation with investment (0.80 and 0.66 , respectively), the model yields a negative correlation between FDI and investment $(-0.39)$.

The last three columns on Table 5 show the impact of costly external financing and search costs for multinationals on the interaction between flows. Consistent with the third stylized fact, the model generates a a negative correlation between FDI and debt but a positive correlation between portfolio equity and debt inflows. As Section 2.3 indicates, the negative correlation between debt and FDI may not be a simple validation that two types of flows are substitutes. Because FDI is the proceeds from a change in ownership from a domestic agent to a foreign ownership, the value of FDI depends both on the number of transactions that occur and the sale price. These two components of FDI may not necessarily move together. The reason the model matches the data so well comes from the cyclical nature of the "valuation effect." As a firm accumulates capital, the option value for the managers of the domestic firm increases and therefore, in a Nash bargain, the sale price must rise. The negative correlation between FDI and debt emerges because the capital stock increases only after the firm borrows from abroad. As borrowing eventually becomes more expensive, firms reduce additional borrowing and more FDI takes place at a relatively high price as firms have built their capital stock using debt. If, alternatively, domestic firms would not have been able to borrow and thus would not have been able to build their capital stocks, the value of FDI may have been low even if the number of transactions were high because the price of those transactions would have been depressed.

To further demonstrate the frictions' impact on capital flow dynamics, Figure 5 plots key macro aggregates simulated responses to a one standard deviation productivity shock. The positive productivity shocks encourage investment and firms finance that investment abroad. While debt (not 
plotted) and portfolio equity flows in immediately to meet the investment needs, FDI falls initially due to the valuation effect and only increases after the capital stock is built up and the foreign value of the firm increases.

\subsection{Sensitivity analysis}

The calibration of the costly external financing function is challenging because the financing costs are both explicit and implicit, making them difficult to document, particularly for Mexico. To show robustness of the results, Table 6 shows standard business cycle statistics for the model solved for differing levels of the bond and equity issuance cost parameters. Several results are worth noting. First, as the financial frictions rise, saving and investment become more correlated. Thus, financial frictions internal to the domestic economy may drive up the time series correlation of savings and investment, as Feldstein and Horioka (1980) conjecture. The correlation of investment with debt and FDI varies slightly with the degree of financial friction. Finally, and more importantly, the correlation between the two types of financial inflows can change depending on the magnitude of the financial friction. The final two columns on Table6 6 show the impact on the relationship between FDI and debt as we alter the parameters of costly search. These parameters may be more closely tied to non-financial institutions within an emerging market. The ease or difficulty of finding a match and the bargaining power of the domestic firm can be linked to many exogenous factors such as distance, information asymmetries, and property rights. The search elasticity and the bargaining power impact the correlation between inflows but exert less of an influence on the correlation of inflows with investment. As the search elasticity falls, the negative correlation between FDI and portfolio equity increases to -0.63 . In terms of the bargaining power, as the domestic agents' bargaining power increases and the multinationals earn less of the surplus, the correlation between debt and FDI falls. This is consistent with the fact that FDI flows seem to be driven by valuation (sale price) effects versus volume (number of sales) effects.

The sensitivity of the results to the calibration is important for explaining the heterogeneity in the composition of flows across various emerging market economies. As Table 1 shows, while debt and FDI are substitutes, the magnitude of the correlation differs by country. In light of the sensitivity analysis, we can link this heterogeneity to both varying degrees of access to external financing captured in the adjustment cost functions for debt and equity and institutional factors in the economy that drive 
search costs.

\section{Conclusions}

This paper provides a theoretical model to disentangle the co-movement between different types of capital flows across the business cycle. We augment the canonical model of a firm financing decision to fit an international framework appropriate for emerging markets. After calibrating the model to Mexico, the simulation results suggest that the model is successful at matching several key stylized facts. First, the model is successful in generating a positive correlation between total inflows and investment as firms use the capital inflows to finance investment. Second, while bonds and portfolio equity tend to move with investment, FDI tends to be counter to investment. Third, we show how costly external finance for domestic firms and search costs for multinationals work together to generate a large degree of substitutability between FDI and portfolio equity as well as between FDI and debt, but a high degree of complementarity between portfolio equity and debt inflows. From the sensitivity results, it is clear that differences in the magnitude of financial frictions in different countries can generate a large changes in the correlations between different types of inflows and between the inflows and investment.

This work suggests that, counter to traditional thinking, the volatility in specific types of flows is not necessarily unhealthy for an emerging market. If, as this work suggests, flows are an equilibrium outcome of firms' financing decisions arising from financial imperfections, then the volatility of capital flows observed in the real world may simply a result of optimizing behavior. Thus, it would be preferable to address the underlying cause of volatility, the institutional features that lead to financial imperfections, rather than to use capital controls to improve domestic welfare. The important next step is to use the framework we presented here to consider the welfare implications of various policies used to control the flow of capital to emerging markets.

\section{References}

Aguiar, M., Gopinath, G., August 2005. Fire-sale FDI and liquidity crises. Review of Economics \& Statistics 87 (3), 439-452. 
Albuquerque, R., December 2003. The composition of international capital flows: Risk sharing through foreign direct investment. Journal of International Economics 61 (2), 353-383.

Alfaro, L., Charlton, A., April 2007. Growth and the quality of foreign direct investment: Is all FDI equal?, Unpublished manuscript.

Altinkilic, O., Hansen, R. S., 2000. Are there economies of scale in underwriting fees? Evidence of rising external financing costs. Review of Financial Studies 13 (1), 191-218.

Bond, S., Meghir, C., April 1994. Dynamic investment models and the firm's financial policy. Review of Economic Studies 61 (2), 197-222.

Chari, A., Ouimet, P. P., Tesar, L. L., Nov. 2004. Acquiring control in emerging markets: Evidence from the stock market. Working Paper 10872, National Bureau of Economic Research.

Christiano, L. J., Fitzgerald, T. J., May 2003. The band pass filter. International Economic Review $44(2), 435-465$.

Eisfeldt, A. L., Rampini, A. A., April 2006. Capital reallocation and liquidity. Journal of Monetary Economics 53 (3), 369-399.

Faria, A., Lane, P., Mauro, P., Milesi-Ferretti, G. M., April-May 2007. The shifting composition of external liabilities. Journal of the European Economic Association 5 (2-3), 480-490.

Faria, A., Mauro, P., December 2004. Institutions and the external capital structure of countries. Working Paper 04/236, International Monetary Fund, Washington, DC.

Fazzari, S. M., Hubbard, R. G., Petersen, B. C., 1988. Financing constraints and corporate investment. Brookings Papers on Economic Activity (1), 141-95.

Feldstein, M., Horioka, C., June 1980. Domestic saving and international capital flows. The Economic Journal 90 (358), 314-29.

Gomes, J. F., Yaron, A., Zhang, L., Winter 2006. Asset pricing implications of firms' financing constraints. Review of Financial Studies 19 (4), 1321-1356. 
Hull, L., Tesar, L. L., 2001. The structure of international capital flows. In: Siebert, H. (Ed.), The World's New Financial Landscape: Challenges for Economic Policy. Kiel Institute of World Economics Symposia and Conference Proceedings. Springer, Heidelberg, pp. 87-109.

Kehoe, P. J., May 1987. Coordination of fiscal policies in a world economy. Journal of Monetary Economics 19 (3), 349-376.

Lee, I., Lockhead, S., Ritter, J., Zhao, Q., Spring 1996. The costs of raising capital. The Journal of Financial Research 19 (1), 59-74.

Mendoza, E. G., October 2006. Endogenous sudden stops in a business cycle model with collateral constraints: A Fisherian deflation of Tobin's Q. Working Paper 12564, National Bureau of Economic Research, Cambridge, MA.

Mendoza, E. G., Oviedo, P. M., October 2006. Fiscal solvency and macroeconomic uncertainty in emerging markets: The tale of the termented insurer. Working Paper 12586, National Bureau of Economic Research, Cambridge, MA.

Mendoza, E. G., Smith, K. A., September 2006. Quantitative implications of a debt-deflation theory of sudden stops and asset prices. Journal of International Economics 70, 82-114.

Modigliani, F., Miller, M. H., June 1958. The cost of capital, corporation finance and the theory of investment. The American Economic Review 48 (3), 261-97.

Pissarides, C. A., September 1985. Short-run equilibrium dynamics of unemployment vacancies, and real wages. American Economic Review 75 (4), 676-90.

Razin, A., Sadka, E., Yuen, C.-W., February 1998. A pecking order of capital inflows and international tax principles. Journal of International Economics 44 (1), 45-68.

Wei, S.-J., 2000. Local corruption and global capital flows. Brookings Papers on Economic Activity $2000(2), 303-354$. 
Figure 1: Rolling Correlations with Investment

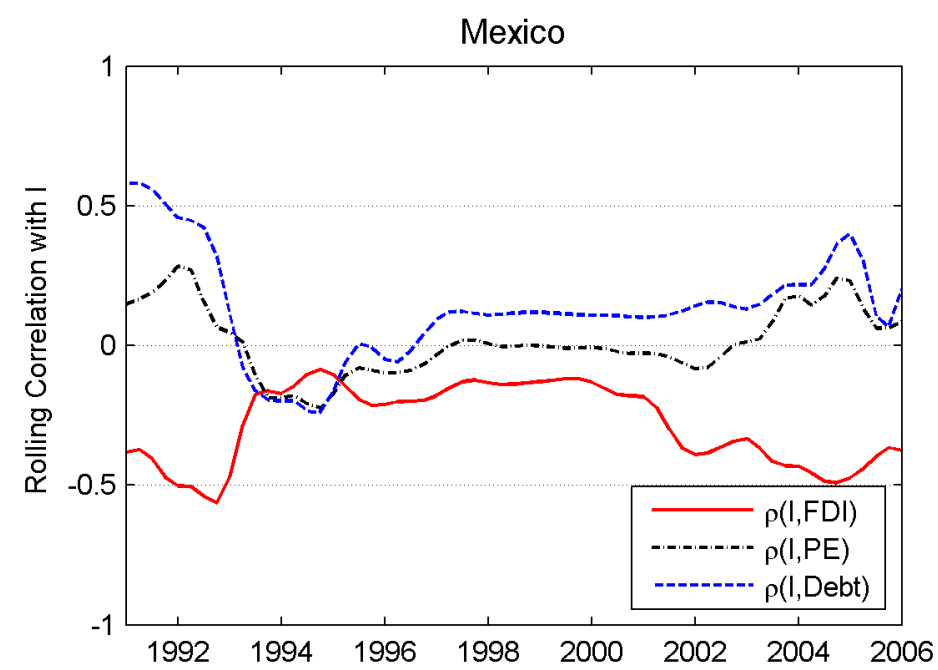

Notes: 10 year rolling correlations. All flows are quarterly gross inflows as a percent of GDP, filtered using Christiano and Fitzgerald (2003) band pass (BP) filter. FDI refers to foreign direct investment, PE refers to portfolio equity, and debt refers to private debt. Investment expressed in real log per capital terms and filtered using BP filter. BP filter removes trend, assumes a random walk, and is symmetric and stationary. First and last 12 observations are lost due to filtering. Data span: 1981Q1-2006Q1. Source: IFS.

Figure 2: Rolling Correlations between Inflows

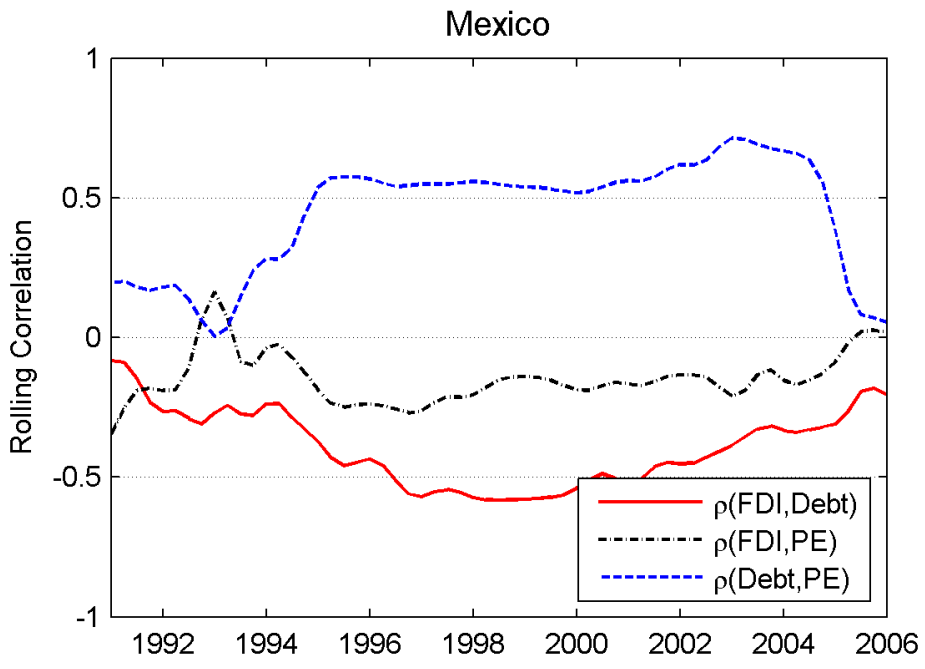

10 year rolling correlations. Notes: All flows are quarterly gross inflows as a percent of GDP, filtered using BP filter. FDI refers to foreign direct investment, PE refers to portfolio equity, and debt refers to private debt. Data span: 1981Q1-2006Q1. Source: IFS. 
Figure 3: Limiting Distribution of Capital

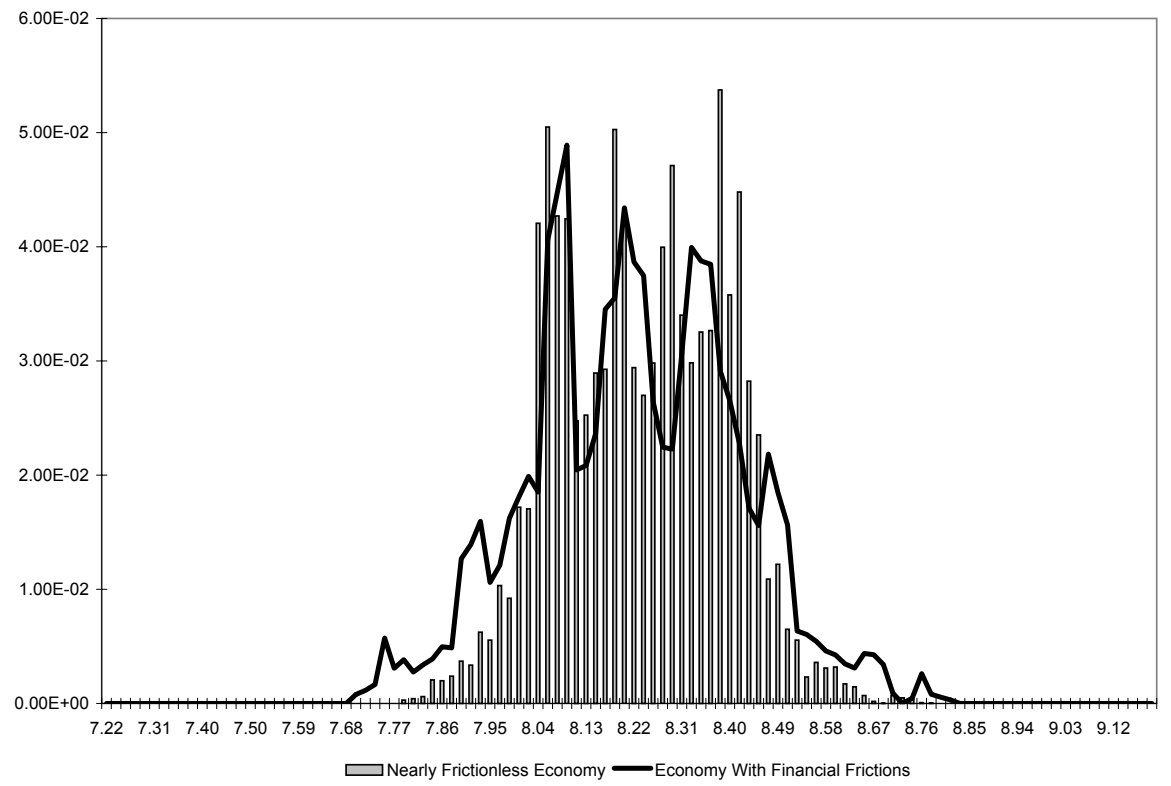

Figure 4: Limiting Distribution of Bonds

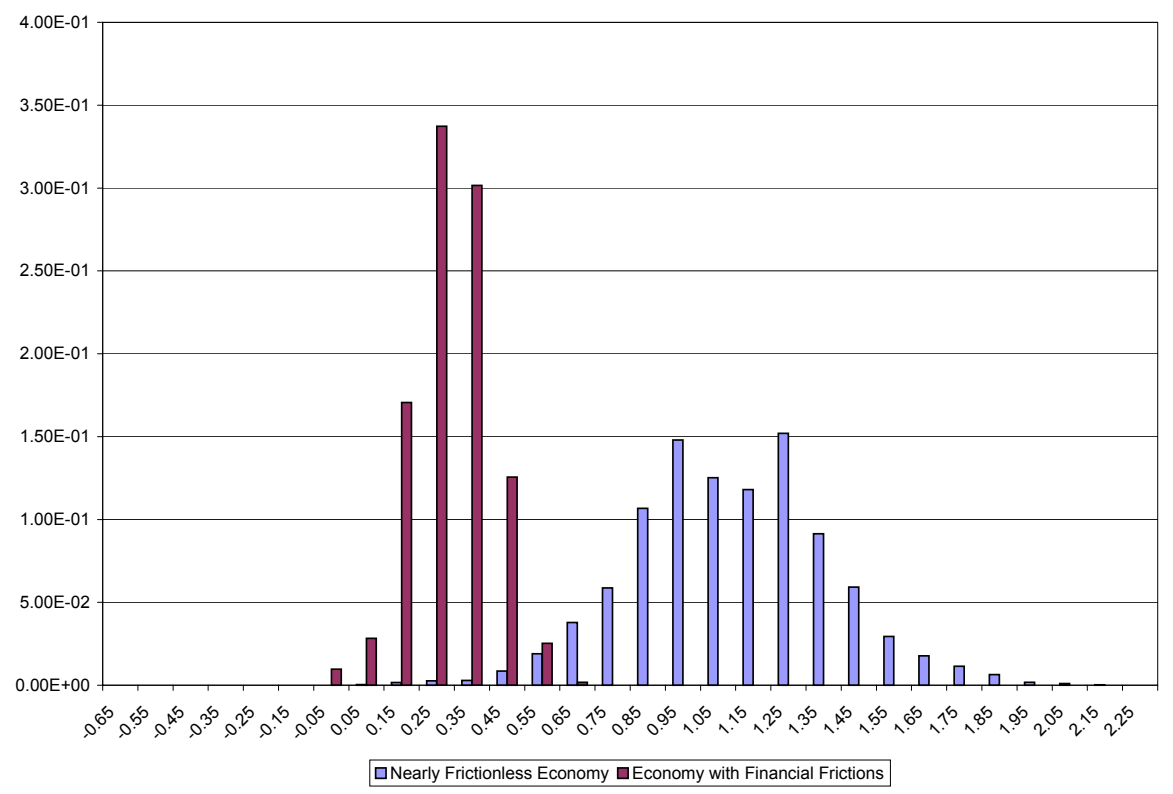


Figure 5: Forecasting Functions

Investment

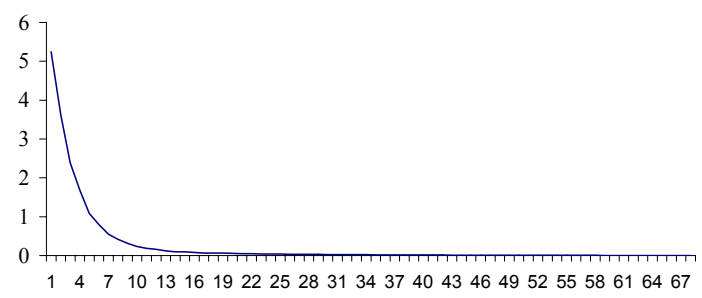

Capital Account

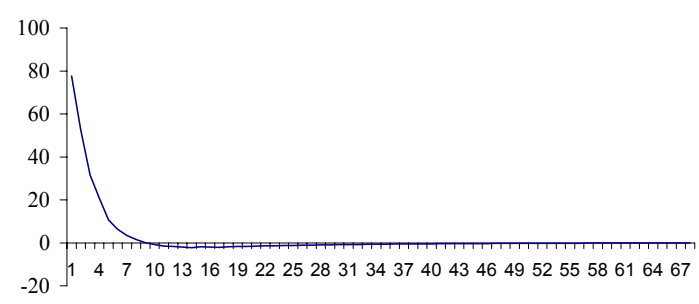

Foreign Direct Investment Inflows

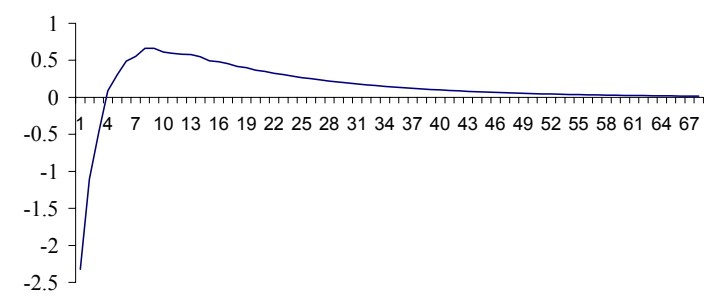

Portfolio Equity Inflows

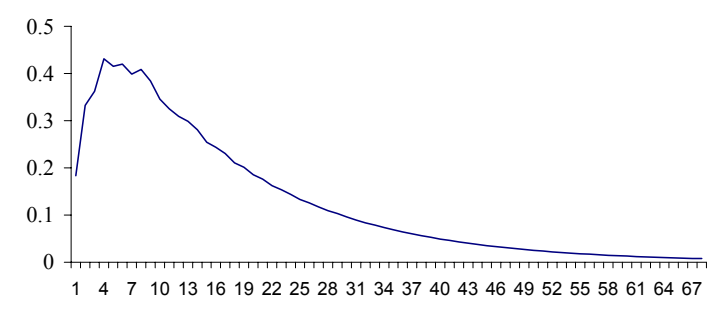

Note: The forecasting functions measure the response to a one standard deviation positive productivity shock as the percent deviation from long run means. The series were simulated based on the benchmark calibration, conditional on the steady state bond position. 
Table 1: Cyclical behavior of capital inflows, contemporaneous correlation with investment

\begin{tabular}{lllll}
\hline & $\rho(\mathrm{I}$, Total $)$ & $\rho(\mathrm{I}, \mathrm{Debt})$ & $\rho(\mathrm{I}, \mathrm{FDI})$ & $\rho(\mathrm{I}, \mathrm{PE})$ \\
\hline Latin America & 0.254 & 0.285 & -0.009 & 0.097 \\
Argentina & $0.793 \dagger$ & $0.733 \dagger$ & $0.271 \dagger$ & 0.009 \\
Brazil & $0.243 \dagger$ & 0.106 & $0.178 \dagger$ & $0.354 \dagger$ \\
Chile & $-0.486 \dagger$ & -0.008 & $-0.541 \dagger$ & 0.015 \\
Mexico & $0.330 \dagger$ & $0.389 \dagger$ & $-0.313 \dagger$ & 0.016 \\
& & & & \\
East Asia \& Pacific & 0.225 & 0.287 & -0.109 & -0.049 \\
$\quad$ Hong Kong & $0.333 \dagger$ & $0.354 \dagger$ & $0.413 \dagger$ & $-0.313 \ddagger$ \\
$\quad$ Indonesia & -0.129 & 0.100 & -0.132 & $-0.243 \ddagger$ \\
$\quad$ South Korea & $0.457 \dagger$ & $0.494 \dagger$ & $-0.171 \dagger$ & -0.012 \\
$\quad$ Thailand & $0.424 \dagger$ & $0.483 \dagger$ & $-0.706 \dagger$ & $0.197 \ddagger$ \\
$\quad$ & & & & \\
Eastern Europe & 0.338 & 0.548 & -0.533 & 0.142 \\
$\quad$ Hungary & 0.028 & $0.434 \dagger$ & $-0.627 \dagger$ & 0.132 \\
Turkey & $0.649 \dagger$ & $0.663 \dagger$ & $-0.439 \dagger$ & $0.151 \ddagger$ \\
\hline
\end{tabular}

Notes: †significant at $10 \%$ level. $\ddagger$ significant at $20 \%$ level. $\rho$ measures the correlation. All flows are quarterly gross inflows as a percent of GDP, filtered using Christiano and Fitzgerald (2003) band pass (BP) filter. FDI refers to foreign direct investment, $\mathrm{PE}$ refers to portfolio equity, and debt refers to private debt. Investment expressed in real log per capital terms and filtered using BP filter. BP filter removes trend, assumes a random walk, and is symmetric and stationary. First and last 12 observations are lost due to filtering. Latin America consists of Argentina, Brazil, Chile, Colombia, Mexico, and Peru. East Asia \& Pacific consists of Hong Kong, South Korea, Indonesia, Philippines, and Thailand. Eastern Europe consists of Hungary and Turkey. Source: IFS. Source: IFS. 
Table 2: Inflow substitutability

\begin{tabular}{llll}
\hline & $\rho($ FDI, PE $)$ & $\rho($ FDI, Debt $)$ & $\rho($ PE, Debt $)$ \\
\hline Latin America & -0.077 & -0.131 & 0.219 \\
Argentina & $-0.871 \dagger$ & 0.015 & $0.197 \ddagger$ \\
Brazil & -0.149 & $-0.351 \dagger$ & $0.448 \dagger$ \\
Chile & $0.377 \dagger$ & -0.105 & $0.271 \dagger$ \\
Mexico & $-0.135 \ddagger$ & $-0.245 \dagger$ & $0.347 \dagger$ \\
East Asia \& Pacific & 0.141 & -0.080 & 0.242 \\
Hong Kong & $0.277 \ddagger$ & 0.196 & $0.373 \dagger$ \\
Indonesia & 0.164 & $0.266 \ddagger$ & $0.781 \dagger$ \\
$\quad$ South Korea & $0.324 \dagger$ & $-0.188 \dagger$ & -0.018 \\
$\quad$ Thailand & 0.077 & $-0.515 \dagger$ & $-0.309 \dagger$ \\
$\quad$ & & & \\
Eastern Europe & -0.196 & -0.431 & 0.143 \\
$\quad$ Hungary & -0.100 & $-0.353 \dagger$ & $0.215 \ddagger$ \\
$\quad$ Turkey & $-0.293 \dagger$ & $-0.508 \dagger$ & 0.071 \\
\hline
\end{tabular}

Notes: †significant at $10 \%$ level. łsignificant at $20 \%$ level. $\rho$ measures the correlation. All flows are quarterly gross inflows as a percent of GDP, filtered using BP filter. FDI refers to foreign direct investment, PE refers to portfolio equity, and debt refers to private debt. Latin America consists of Argentina, Brazil, Chile, Colombia, Mexico, and Peru. East Asia \& Pacific consists of Hong Kong, South Korea, Indonesia, Philippines, and Thailand. Eastern Europe consists of Hungary and Turkey. Source: IFS.

Table 3: Summary statistics: Mexico

\begin{tabular}{llrrrrrr}
\hline & $\sigma_{i}$ & $\sigma_{i} / \sigma_{y}$ & $\rho(\mathrm{i}, \mathrm{Y})$ & $\rho(\mathrm{i}, \mathrm{I})$ & $\rho(\mathrm{i}, \mathrm{Debt})$ & $\rho(\mathrm{i}, \mathrm{FDI})$ & $\rho(\mathrm{i}, \mathrm{PE})$ \\
\hline GDP & 2.079 & 1.000 & 1.000 & 0.760 & 0.337 & -0.266 & 0.125 \\
Investment & 7.705 & 3.705 & 0.760 & 1.000 & 0.389 & -0.313 & 0.016 \\
Consumption & 3.324 & 1.599 & 0.854 & 0.549 & 0.366 & -0.102 & 0.104 \\
Saving & 2.875 & 1.383 & -0.170 & 0.165 & -0.165 & -0.224 & -0.068 \\
Current account (\% GDP) & 0.483 & 0.232 & -0.716 & -0.611 & -0.393 & 0.068 & -0.013 \\
Total Inflows (\%GDP) & 0.804 & 0.387 & 0.306 & 0.330 & 0.979 & -0.119 & 0.485 \\
Debt (\% GDP) & 0.767 & 0.369 & 0.337 & 0.389 & 1.000 & -0.246 & 0.348 \\
FDI (\% GDP) & 0.111 & 0.053 & -0.266 & -0.313 & -0.246 & 1.000 & -0.135 \\
PE (\% GDP) & 0.139 & 0.067 & 0.125 & 0.016 & 0.348 & -0.135 & 1.000 \\
\hline
\end{tabular}

$\sigma_{i}$ is the standard deviation reported in percentage terms. $\sigma_{i} / \sigma_{y}$ is the ratio of the standard deviation relative to GDP. $\rho(i, j)$ is the correlation of the row with series $j$. All flows are quarterly gross inflows as a percent of GDP, filtered using BP filter. FDI refers to foreign direct investment, PE refers to portfolio equity, and debt refers to private debt. Investment and consumption expressed in real log per capital terms and filtered using BP filter. Data span: 1981Q1-2006Q1. Source: IFS. 
Table 4: Simulated Business Cycle Statistics I

\begin{tabular}{lrrrr}
\hline & $\sigma_{i}$ & $\sigma_{i} / \sigma_{y}$ & $\rho(i, Y)$ & $\rho(i, I)$ \\
\hline Nearly Frictionless SOE & & & & \\
GDP & & & & \\
Investment & 2.27 & 1.00 & 1.00 & 0.27 \\
Consumption & 20.07 & 8.83 & 0.27 & 1.00 \\
Current Account (\%GDP) & 1.00 & 0.44 & 0.42 & 0.02 \\
& 5.66 & 1.15 & 0.07 & -0.94 \\
\hline SOE with Financial Frictions & & & & \\
GDP & 2.21 & 1.00 & 1.00 & 0.58 \\
Investment & 9.66 & 4.38 & 0.58 & 1.00 \\
Consumption & 1.12 & 0.51 & 0.77 & 0.28 \\
Current Account (\%GDP) & 2.19 & 0.46 & -0.03 & -0.81 \\
\hline & & & & \\
Mexican Data & & & & \\
GDP & 2.08 & 1.00 & 1.00 & 0.76 \\
Investment & 7.71 & 3.71 & 0.76 & 1.00 \\
Consumption & 3.32 & 1.60 & 0.85 & 0.55 \\
Current Account (\%GDP) & 0.48 & 0.23 & -0.72 & -0.61 \\
\hline
\end{tabular}

Note: The nearly frictionless model is calibrated with relatively very small financing costs on bond issuance and no search or portfolio equity costs. $\sigma_{i}$ represents the standard deviation. $\sigma_{i} / \sigma_{y}$ is standard of deviation ratio with GDP. $\rho(i, y)$ is correlation with GDP. $\rho(i, I)$ is correlation with investment.

Table 5: Simulated Business Cycle Statistics II

$$
\rho(i, Y) \quad \rho(i, I) \quad \rho(i, D e b t) \quad \rho(i, F D I) \quad \rho(i, P E)
$$

\begin{tabular}{lrrrrr} 
SOE with Financial Frictions & & & & & \\
Total Inflows (\%GDP) & 0.03 & 0.81 & 0.99 & -0.20 & 0.14 \\
Debt (\%GDP) & 0.08 & 0.80 & 1.00 & -0.18 & 0.11 \\
FDI (\%GDP) & -0.13 & -0.39 & -0.18 & 1.00 & -0.57 \\
PE (\%GDP) & 0.86 & 0.66 & 0.11 & -0.57 & 1.00 \\
\hline & & & & & \\
Mexican Data & & & & & \\
Total Inflows (\%GDP) & 0.31 & 0.33 & 0.98 & -0.12 & 0.49 \\
Debt (\%GDP) & 0.34 & 0.39 & 1.00 & -0.25 & 0.35 \\
FDI (\%GDP) & -0.27 & -0.31 & -0.25 & 1.00 & -0.14 \\
PE (\%GDP) & 0.13 & 0.02 & 0.35 & -0.14 & 1.00 \\
\hline
\end{tabular}

Notes: $\rho(i, y)$ is the correlation with GDP. $\rho(i, I)$ is the correlation with investment. $\rho(i, D e b t)$ is the correlation with debt inflows as a percent of GDP. $\rho(i, F D I)$ is the correlation with FDI as a percent of GDP. $\rho(i, P E)$ is the correlation with portfolio equity inflows as a percent of GDP. 


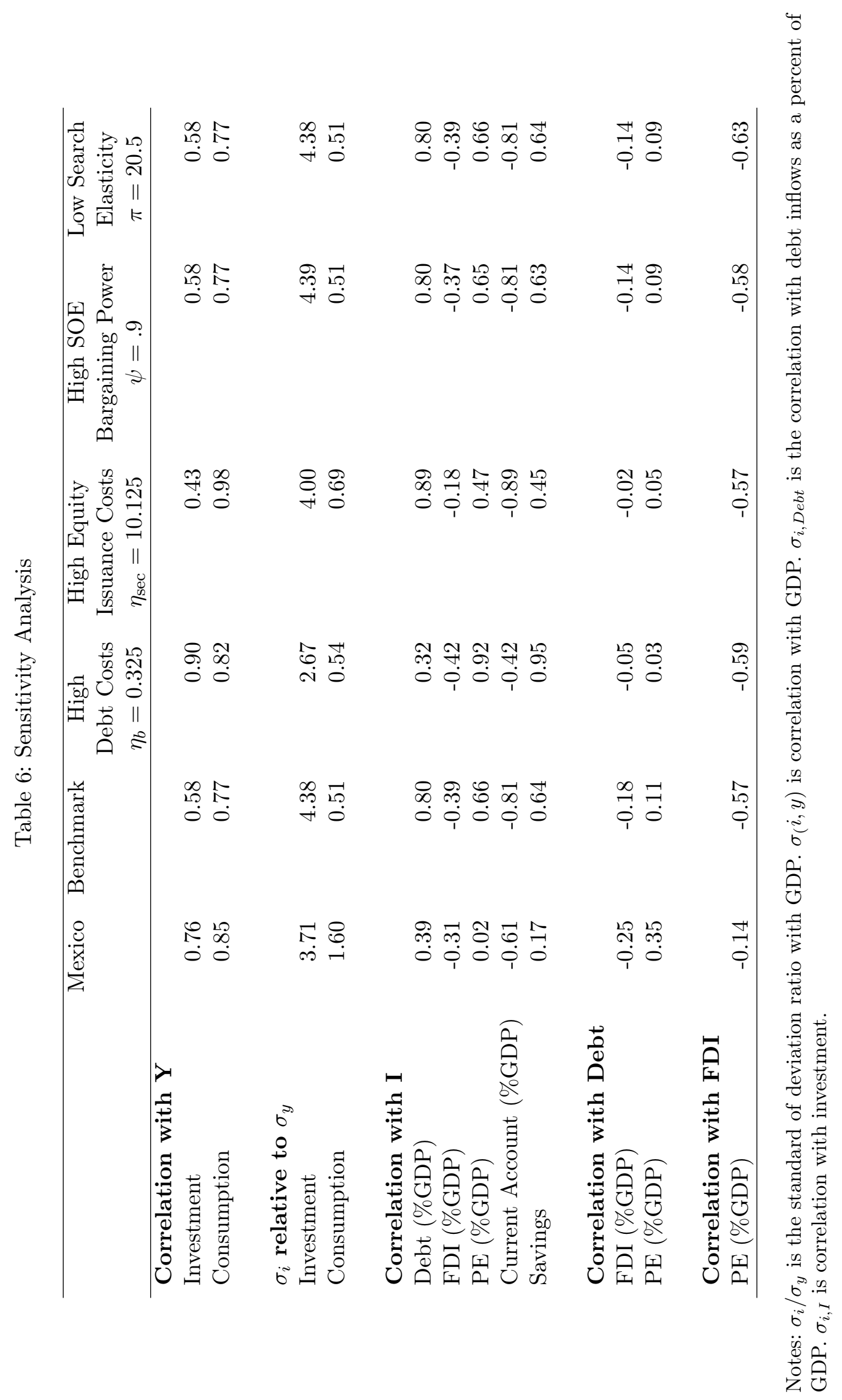

